\title{
Zuazo in Caracas: The urbanism of exile in Venezuela, $1937^{\dagger}$
}

\author{
Carlos Sambricio* \\ Departamento de Composición Arquitectónica, ETS Arquitectura de Madrid, Madrid, Spain
}

\begin{abstract}
The urbanism of the 1920s and 1930s was marked by the debate over the avant-garde and in Spain during this time there were two points of reference: those who (based in Barcelona, with Sert at the helm) follow the directions of Le Corbusier and those who, from Madrid, opted for German architectural influences. But there was even a third option: that of Secundino Zuazo (arguably Madrid's principal architect before 1936) who in 1926 backed by a French initiative - organized a study to define the urban problems of the principal Spanish cities, find solutions and present them to the municipal governments along with the necessary financial backing. In 1929 Zuazo obtained - together with Herman Jansen of Berlin - first place in the Competition held for the extension of Madrid, supporting the Project at the same time with its own financing. From that experience, during the Spanish Civil War Zuazo was invited by the Venezuelan government to go to Caracas to put together a study of that city.
\end{abstract}

Keywords: Zuazo; Jansen; public housing; inter-war Spanish urbanism; Venezuela; Caracas

In 1938, shortly before the end of the Spanish Civil War, the Madrid architect Secundino Zuazo received two invitations to visit Paris. First, Venezuela's consul general in Europe communicated to him an official assignment to head the transformation of Caracas, also inviting him to head for that country and manage the project. At the same time, Colombia's minister in Paris, Gregorio Obregón, informed him that President Santos wanted him to travel to Bogotá. In the Memorias (Memoirs) he wrote years later (and published recently) he describes both encounters:

Venezuela's Consul General in Europe held meetings with Spaniards who, like me, were isolated from the Civil War: the engineer Valiente and the politician Álvarez Mendizábal. I was invited to one of those meetings. With the consul there was discussion about the possibility of drawing up, through a group of Spanish technicians, possible ideas to take to Venezuela. They considered me because they believed that my knowledge of urban planning could be usefully applied to the city of Caracas, in need of transformation ... The consul encouraged me and supplied me with basic maps of the country and the city of Caracas ... I sketched out Caracas and its streets with my ideas for transforming them. I wasn't going to travel to Venezuela with empty hands. The result of my brief study was the beginning of a project that continued uninterrupted during the time I spent in France. The outline that I drew is included here ... it is how I envisioned the transformation of the Venezuelan capital. ${ }^{1}$

The invitation to travel to Bogota was made via the well-known intellectual Gregorio Marañón, friend of President Eduardo Santos. Zuazo would design the Presidential Palace and a ministerial building, formulate an action plan, and budget the works, proposing a total

\footnotetext{
*Email: csambricio@hotmail.com

${ }^{\dagger}$ This article is dedicated to Fernando Terán on the occasion of his retirement. This is translated from the Spanish by Dr Christopher Hull, University of Nottingham, UK.
} 
sum that Colombia hoped to obtain as a loan from the US government. The proposal's uniqueness rested in the fact that the architect was asked to act as both constructor and contractor, ensuring him the budget he had proposed. While Franco's government manoeuvred - via its ambassador in Paris - to prevent Zuazo's departure, it is interesting to reflect on both invitations. In contrast to the firm Colombian proposal on the one hand, Venezuela proposed that he travel there without advising him of its existing contacts with a French urban planning team headed by Henri Prost and working with Rotival y Lambert. They had also not told him that the 'Commission of Urban Works' had already signed the contract for the team's urban plan. ${ }^{2}$ The Colombian invitation proves not only to what degree its government was aware of the architect's planning talent but also of his experience in construction and business, evidenced by his work in Spain from the beginning of the 1920 s and co-operation with banks on numerous property projects. The Venezuelan proposal, as he himself would recognize in his Memorias was undefined, and demonstrated only that "... my knowledge of the urban environment could prove valuable when applied to the city of Caracas'. It would also be interesting to imagine what would have resulted had Zuazo the businessman indeed left for Latin America at a time, let us remember, when Rotival was proposing changes in Caracas and when Karl Brunner from Vienna had made public - in 1933 - his proposal for land development in Bogotá. ${ }^{3}$

Unlike those who left Spain for exile without even knowing what work they would undertake, or where they would set up home, Zuazo received personal invitations from two governments to move abroad and lead specific projects. This figure, unanimously considered as a reference point for architectural expertise and experience in Madrid, found - even before the Civil War had finished - that at least two doors were open to him if he chose exile. Félix Candela would go into exile when he travelled to Mexico, as would Josep Lluís Sert when he went to Harvard, Antonio Bonet to Buenos Aires, and Martín Domínguez to Havana... There were many from the architectural profession who abandoned Franco's Spain in 1939 to take refuge in Latin America, a neutral region in the conflict, and able to rely on economic funds to develop and transform its cities. ${ }^{4}$ But the exceptional thing about the proposal made to Zuazo was not just the commission to redesign and rethink the urban layouts of capital cities as important as Caracas and Bogotá, but his agreement that, with the project designed, he could bring in his own team and manage it himself. Its uniqueness rested in the fact that not only was he an urban planner capable of conceiving large proposals, but that above all he was a technician/entrepreneur well accustomed to dealing with international banks, and obtaining finance and loans to transform a country's infrastructure.

Zuazo arrived in Paris in 1938, fleeing from the threats of anarchist groups who aimed to seize some of his properties. He left Franco's Spain, loyal to the Republican government until the very end. His departure has to be understood both as a defection, and without doubt, as a way of protecting himself and the lives of his family. In Paris he was visited by Pedro Muguruza - already made responsible for architecture by the first Franco government - who would propose that he lead (once the triumph of the rebellious troops was clear) the reconstruction of Spain in exchange for declaring his support for the new regime. Zuazo's refusal would mean, once the war was over, that he would suffer professionally, with a 'political misconduct' charge directed against him. Anyone who had ever held a public post or been a member of a political party was forced to spend 4 years in the Canary Islands under 'forced residence', a euphemism used by the Franco regime as an alternative to the stronger term 'deportation'. A practising Catholic, property businessman, and consultant of international banks in land 
deals, sympathizer of the centre-right and first Dean of the recently constituted College of Madrid Architects, he was also opposed to the Franco rebellion (a position he maintained throughout his life). From this moment forward he would live - until the end of his life in 1969 - a long 'internal exile'.

Recognized by everyone in Madrid before the war as a reference point for architecture, his opposition to Franco's military coup meant that not only were his existing contacts with banks ended, but he was also marginalized professionally. He was forced to reflect in silence as many of his urban projects were taken over, altered, and distorted by the architects of the victorious 'Nuevo Estado' ('New State'). From the end of the 1920s until the Civil War, Zuazo's architectural practice had been the meeting point for Madrid's most brilliant architects and engineers, for example: García Mercadal (one of those at the La Serraz meeting); Arniches and Martín Domínguez (authors of Madrid's Hippodrome); as well as Eduardo Torroja (chief engineer of the Hippodrome buildings and those of Frontón Recoletos in Madrid). His professional career had begun at the beginning of the $1920 \mathrm{~s}$, when, at the request of the businessman who gained the contracts for Madrid's Gran Vía, he project managed these works. It was at this time that he conceived the novel idea that the architect's responsibility was to plan in such a way that the client earned the maximum profit possible from capital invested, and at the same time, that the developer should always rely on the best architect. Zuazo found the solution to this double collaboration when he decided to become the developer on his own projects.

Partner since the 1920s of Manuel Mañas (the lawyer responsible for urban management on Madrid's city council), Zuazo found in him the perfect collaborator for work with various city councils. Seeking protection under the 1885 Suburbanization and Cleansing of Towns Law, when planning the transformation of the historic heart of Bilbao, he designed proposals at the same time for the suburban expansion of Seville and Zaragoza. Conscious that city councils lacked technical and economic resources he created a Research Society, announced in the press and offering its services to city councils, large companies, and investment groups. While at the beginning, as he recognizes in his Memorias, the Society simply offered a range of administrative services, Spanish banks soon used it to produce reports, and immediately afterwards international banks (Dreyfus of Paris, Morgan's Bank and the Consortium Comercial pour l'Etranger) invested in an office for it to carry out the same work for them. ${ }^{5}$

While Zuazo's early ambition had been to bid for/obtain/design/develop/manage several small urban projects, his method of working changed when he became involved with banks. He then received commissions to study the urban environment of the principal Spanish cities, investigating their needs and deficiencies, designing solutions, and, in view of this, facilitating contact between banks and the relevant city councils to offer them credits for the works in question. From this moment in time the scale of his projects changed. He became involved in work as diverse as Madrid's rail system, and a fantastic project for a tunnel under the Gibraltar Straits, designing a garden city for each of its entrances. But as he himself recognized '... he received guidance on the two big projects that Madrid needed to undertake: the Castellana extension and the plan for internal alterations'. 6

From a strictly economic point of view, Spain lived through distinct periods in the $1920 \mathrm{~s}$. It benefitted from its neutral status during the First World War by expanding its industrial base, necessitating the construction of housing for immigrants to the city, legislating in favour of city councils and employers to support the construction of workers' housing. In around 1926, the dictatorship of General Primo de Rivera (who had come to power through a 
military coup in 1923) radically changed economic policy, adopting what in Weimar Germany was called a Revolución Conservadora. Abandoning old policies for economic housing it laid out three big state projects: first, a law for approving the construction of arterial and ring roads, putting out to tender $2000 \mathrm{~km}$ of linking routes; then, the Preferred Plan for Urgent Railway Construction that involved the electrification of $2500 \mathrm{~km}$ of track; and last, an ambitious plan of hydraulic works that would give rise to - through optimum use of water - the so-called Hydrographic Confederations (the name given to the separate projects that planned to utilize Spain's principal river basins), bodies with full autonomy and legal status. ${ }^{7}$ Hoping to define a large-scale project, applying what Frank Neumann - in reference to pre-1939 Germany - designated in Behemoth as la vocación más racional (the most rational vocation), and conscious of how much the well-being of a national community could only be protected by the state, such initiatives were concluded at a time when engineers performed a single role. In the same year the three most important construction companies (Agromán, Entrecanales y Huarte) were founded in Spain, and international banks supported the above projects with loans.

From the beginning, Zuazo was one of the technical team that advised the government and the debate about the existence of a National Plan capable of bringing together transport policies for road and rail, as well as agriculture and mines. This led to the meeting in 1926 of the First National Congress of Urban Planning where, as well as other conclusions, it demanded that the government pass into law the obligation of all municipalities with populations over 50,000 to formulate a plan for urban expansion, trusting that the investment of private capital would stimulate the economy. Zuazo not only took part in the Congress as a member of the organizing technical commission but he also presented a draft proposal on the 'Internal Alteration of Towns', commenting on his own experience of the subject. He also presented at this time a plan for a new railway station for Madrid, showing off the work carried out by his Research Society and highlighting its key role in the urban debate. From this desire to encourage change the administration organized an exhibition entitled 'The City and Modern Housing', encouraging the construction of high-rise blocks (of high density) for cheap rented housing. Demanding the approval of the Urban Planning Law, the debate about modern housing took a new direction and magazines published examples of housing constructed in Central Europe, abandoning the regional pastiche that had prevailed until shortly earlier. At this juncture Zuazo performed two roles: taking interest in a new urban image, and simultaneously demanding the rejection of ornamentation in architecture.

Zuazo's prestige derived from his work as an architect in the early part of the decade, when he championed an alternative to regional pastiche, demanding in its place reflection on tradition. In 1920 a group of professionals - among whom, apart from him, were Bastida from Bilbao, Amós Salvador from Madrid and Rubió i Tuduri from Catalonia (all three concerned with the construction of cheap housing) - attended a Congress in London where they debated criteria to adopt for the reconstruction of Europe, discussing the possibility of reducing the cost of cheap housing through the standardization of popular architecture. In one way or another, the experience that Paul Schmitthenner had developed in Berlin's Gartenstadt Staaken (defining elements that tended to be combined in distinct ways) was going to be a reference point for those who became concerned about the construction of cheap housing. One only needs to study the reflection that Alberto Libera would formulate on popular Italian architecture, and analyses of cheap housing carried out by members of the Amsterdam School, plus the writings of Torres Balbás, 
Bastida or Rubió i Tuduri, to understand how an alternative emerged out of a reflection on the popular and tradition. ${ }^{8}$

Opposing those who aimed to make a clean break with the society that had produced the horrors of the Great War (demanding, like Gramsci, a Ordine Nuovo; like Cocteau, a Rappel a l'Ordre, or like Le Corbusier, a Esprit Nouveau), others searched for concrete solutions to specific problems, concerned to give the working classes access to sanitary and affordable housing. The effects that the conflict had on Spanish architecture were important. Given that industries in the warring countries had been re-orientated for wartime production, Spain took advantage of the demand for basic materials to stimulate its industry. Such developments encouraged migration from the countryside to the city, requiring the construction of housing for new urban dwellers, at a time when any new investment caused the price of cement, bricks, plaster and iron for construction to quadruple in price in just a few years. Construction was simplified and all decoration was eliminated in order to reduce costs. This led to a surprising contradiction: houses for the rich middle-classes had multi-coloured neo-baroque or pseudoregionalist decoration while the rooms of workers were designed without adornment. The new choices about the future of architecture ran in parallel to the discussion about its function and the role of the architect: common ground was the rejection of the image of the city transformed into allegory, and adoption of what a young Sigfried Giedion had demanded in a 1918 essay on architecture '.. abandon the I,... abandon urgency and choose tranquillity ... leave behind charm and adopt harmony'?

Attempting to apply Taylor's advice on economics to architecture, there was a desire to redefine ease of movement inside homes and both normalize and standardize (thus reducing costs) certain traditional construction principles. A return to studying the popular was made not to nostalgically recover lost designs but to understand how much tradition had been able to refine designs and usages. Distinguishing the tradition of conservative thought (tradition belongs to us all; conservative thought was the choice that those behind the French Revolution denied, like Taillerand, Maistre and Chateaubriand, the concepts of equality, fraternity and liberty) the idea was to standardize the vernacular, in tune with Ortega, who highlighted the importance of Escorial and Quixote with regard to new ways of thinking. This mimicked how Machado and Azorín extolled the virtues of Castilla, while Cossio - through Pedagogic Missions concentrated his gaze on the popular, disseminating general culture, modern teaching guidance and education in towns and villages, paying special attention to the rural population's spiritual interests. ${ }^{10}$ It was in those years when Manuel de Falla abandoned Stravinski's impressionism, opting for popular roots, and when Torres Balbás called for tradition, García Mercadal studied Mediterranean housing, and García Lorca employed folklore-inspired music to inform his theatre and poetry. And, by the same token, Eugenio d'Ors theorized in Catalonia about all things Mediterranean, taking as his reference point Ampurias and demanding, despite everything else, the need for a Catalunya-ciutat (Catalonian-type city) to reflect modernity, in opposition therefore to those that defended the idea of a rural Catalonia.

Architectural culture in the Spain of the 1920 s depended on what was happening in Barcelona and Madrid, both with their own characteristics. Barcelona focused its attention on Parisian culture while Madrid (a reflection of Krause's presence years earlier) preferred German culture. There were various architects who from 1919 were influenced by Ortega - a student at the beginning of the century of Dilthey, Simmel and Sombart - and travelled to Germany to learn both from the experience of the old masters of urban planning and the proposals drawn 
up in Berlin and Vienna by another young generation. Interested in understanding the policies of local municipalities that provided cheap land (thus facilitating the construction of workers' housing), they valued bylaws that controlled big town expansion and they studied transport systems that permitted access to the metropolis from remote locations. Between 1926 and 1929 the debate about Madrid's urban development reached a great intensity, and the city council organized an International Competition for Planning the Outskirts and the Interior Renovation of the city. And it was then that Hermann Jansen - who in 1910 had won the competition for Greater Berlin - joined up with Secundino Zuazo to enter the aforementioned competition.

As I have pointed out, in around 1926 the state of the Spanish economy was buoyant, unlike that in Weimar Germany. There, following the war, a young generation of architects had replaced their masters in their municipal posts. This meant that those who at the beginning of the century had come together at the seminar led by Brix at the Charlotenburgo School were marginalized by 1920. And seeking new opportunities was how Otto March, Otto Bünz, Joseph Stübben, Otto Czekelius and Hermann Jansen came to take part in various urban planning competitions celebrated in diverse Spanish cities, always working alongside local architects. ${ }^{11}$

The first news in Spain about Jansen's professional work had been circulated by Cipria de Montoliú, when commenting about the 1910 exhibition organized by Hegemann in Berlin. This highlighted both the special nature of the Competition for the Berlin Großstad and the planned garden suburb in Schöneberg - close to Tempelhof - where, because the price of land for the construction of single-family housing was extremely inflated, he had proposed four-storey block-sized apartment buildings, with large open interior patios, grouped around a large open space. $^{12}$ This idea opened up new alternatives to the English model of the single-family house. It was latent in Zuazo's design for the 1928 'Casa de las Flores' project in Madrid, for an apartment block grouped around a large open space. Here - converted again into businessman and architect - he planned and constructed an apartment block that occupied an entire block of the Ensanche, designing up to 13 types of rented housing that included 10 twin-houses with four homes on each floor. ${ }^{13}$ His idea was to demonstrate the best and most convenient use of land, obeying at every turn municipal byelaws, but giving to the houses an interior open space, more spacious and more attractive than that seen in the streets around Ensanche. The size of street buildings was the same as that demanded by the byelaw and the compensation for the loss of space from the two open spaces that aired and gave light to the interior was compensated by the larger height of the inward-facing space. Attempting to optimize the small interior patios that existed in the buildings of the Ensanche (patios without even any ventilation) he conceived two parallel units, each consisting of five houses and each separated from the other by a large garden. At the same time, in each one of these sections he introduced housing zones, both with a large service patio, interrupted by lift and stair towers. The regulation adopted did not limit itself to separating the two halves of the apartment block, but rather widening the pavements. That apartment block, due to its height and the design of its interior garden, and the proposals for housing with service areas spilling onto patios, was soon in Madrid the reference paradigm for a modernity most aligned with the New Objectivity. It was not the type of architecture defended in the 1928 Congress organized by Le Corbusier in La Sarraz.

The first to classify for the Competition for Planning the Outskirts of Madrid was the ZuazoJansen pairing. While the last great project constructed by Zuazo before entering the Madrid 
competition had been the 'Casa de las Flores', Jansen's trajectory was very different. A disciple of Henrici en Aquisgrán, after winning the competition for Berlin's Großstad he produced plans for different areas of this city (Tiergarten, Tegel, Zehlendorf, Wedding ...), becoming renowned outside Germany for designing proposals for Prague, Ankara and Stockholm. ${ }^{14}$ The magazines from those years reflect the exceptional interest that German urban culture provoked in that period, decisive for Madrid architects who developed professionally between 1925 and 1936 . A ridiculously erudite but very revealing statistic confirms this. A study of German architecture magazines and subscriptions from European countries between 1931 and 1933 produces surprising results. As opposed to the 315 subscriptions for Moderne Bauformen in France in 1931 (385 in 1933), or the 60 from England in 1931 (56 in 1933), in Spain 170 subscriptions in 1931 rose to 431 in $1933 .{ }^{15}$ In just 2 years the number of subscriptions from Republican Spain rose extraordinarily, compared to a slight recovery in France and an actual fall in England.

It was García Mercadal, Jansen's student in the Charlotenburgo School in Berlin and then collaborator in Zuazo's studio, who organized the competition. He requested from Jansen the name of a Spanish expert on urban themes, and was given the name of the Spanish master. Work on Madrid was made less complicated because the competition counted on excellent documentation distributed to the participants (Report on the City edited by Fernández Quintanilla) ${ }^{16}$ that analysed the historical development of Madrid and also highlighted three plans: a project for creating zones, a north-south axis layout that would link the area surrounding the River Manzanares to Chamartín, and the basis of a Regional Plan that prioritized a circular railway system proposal. Drawing up a north-south axis as the backbone of a plan, locating population centres on the city outskirts, and establishing the basis of internal alterations, were all challenges that both Zuazo and Jansen had encountered and resolved in a range of projects. I understand that Zuazo established the outline of the project, and they divided the workload between them. The evidence for this is seen in Jansen's original sketches, found in the Plansammlung del Kunstwissenschaft Institut of the Technische Universität in Berlin, as well as drawings located in the Zuazo archive in Madrid's National Library. ${ }^{17}$

The Berlin drawings demonstrate how Jansen approached the plan for the outlying districts. He proposed a zoned system for the city, with new industrial districts, a residential district, and a detailed study of how - in his opinion - the extension of the Paseo de la Castellana should be conceived. At the same time Zuazo concentrated on alterations to the city centre, indicating how to lay out the new infrastructure, as well as analysing - based on criteria different from those set out by the German - the vision for the Castellana axis. The discrepancy between their points of view was reflected in the drawing of the new axis and I understand that the proposal presented to the competition was a synthesis of both, devised and chosen by Zuazo. While his initial idea had been to repeat on the Castellana the closed block system of the Ensanche planned for the "Casa de las Flores', in the resulting proposal he abandoned his original idea and adopted the open block defended by Jansen, although he altered the width of the axis and modified some of the details from the Berlin plans.

Twelve plans entered the competition. The jury argued, however, that the entry conditions had not been obeyed. They did not award a first prize, although they highlighted the Zuazo and Jansen proposal as the best. The jury minutes, far from being a simple administrative document, with 'recommendations' by jury member Paul Bonatz (published in the Madrid magazine Arquitectura), soon became an important reference for those who tried to define the new axis as well as the proposal to establish a series of satellite districts around the metropolis. ${ }^{18}$ Zuazo 
established the general outline of the proposal and the German's responsibility was to graphically formalize the Regional Plan with an open residential block on the Castellana. After the city council rejected the project and after its technical office drew up variations on the proposal, Zuazo took advantage of the political ambitions of the President of the Council of Ministers in 1932 to construct a large building - occupying the land of the old Hippodrome - for the Nuevos Ministerios. After receiving the commission for this project, he relaunched the Castellana plan with the novel idea to fund it through an international bank loan. Thanks to this, and taking advantage of the fact that the jury had highlighted his proposal over the others, Zuazo the businessman was aware that the only way to progress with the plan was to guarantee its execution, and his main achievement was to be given the assignment by the city council, expressed in private agreements for financing the work. However, when the formalities were already set out and it was possible to draw up a contract and formalize the assignment, the Socialist minority put a stop to it, gaining from the Corporation a municipal agreement through which the development of the idea was entrusted to the Municipal Technical Office (OTM).

The OTM, the team led by Bellido and including Lacasa, Escario and Colas, proposed an alternative to Zuazo's solution. After studying the characteristics of the apartment blocks they designed different types of cells for each floor, taking as a reference the projects designed by German architects (from society cooperatives, from the proceedings defined by May in Frankfurt, or from the work of the GEHAG in Berlin), with the idea that constructed homes should be rented out, creating a range of possibilities that depended not on the requirements of families but on the level of rent. The difference between the Zuazo and OTM proposals rested in their administration. While for the OTM architects it was the city council that had to lead the project, Zuazo subordinated the realization of the plan to a private entity with a financial interest in its execution. He criticized the OTM's lack of skills, its urban vision, and planning on too small a scale. He condemned the fact that it had given a negative response to his request to expropriate $100 \mathrm{~m}$ on each side of the Castellana, for this was the only way of obtaining land that could thence rise in value. The conflict was about resolving who should have access to that land. Zuazo recognized that adding value risked infringing the competition's aesthetic criteria. He therefore criticized those who hoped to replace "... that magnificent spread of green spaces and important buildings ... with just buildings, thus attracting possible investors who would take the project forward'. ${ }^{19}$ Instead it was necessary, he insisted, to alter planning rules in order to make construction more financially viable. For that it was necessary to lay down mechanisms for expropriation and urbanization, and create new spaces for construction. To this idea Zuazo added an innovation to previous solutions. After conceding the argument about open versus closed apartment blocks, he proposed that the Castellana extension create open apartment blocks (unlike the closed of the 'Casa de las Flores') that were consistent with the values debated by the Central European architects of the Modern Movement at the CIAM (Congrès Internationaux d'Architecture Moderne) in Brussels.

He therefore proposed to alter the idea he had presented in 1929. While at the start the ZuazoJansen pairing had proposed four different types of homes on the Castellana (open apartment blocks: accommodation aimed at the upper class, the middle class and the working class), Zuazo the businessman (with the Republic in a critical economic state) understood that the only way of making the project a reality was to attract the interest of possible investors. He proposed that private concerns be given the right to expropriate a 100 -metre-wide strip on either side of the axis. After carrying out different economic studies demonstrating the viability of the proposal (providing that private money constructed the axis) and setting down time 
limits, he judged that the solution was to tender out the project to those capable of attracting property investment. For this reason, he studied again the rail system proposal to establish access routes for the circular railway to the capital at the same time as deciding where to locate the stations and resolving the link between the old and the new stations via a north-tosouth running tunnel. He drew up the plan during a period of important political change, the transition from monarchy to the Second Republic. In 1930 the then mayor spoke to Zuazo in an attempt to see how the proposed ideas could be set in motion. Due to this Zuazo made contact again - through a new Society, Public Works, Improvements and Constructions SA - with foreign banks and, as indicated in his documents "... the city council agreed to the assignment and it became a reality, following private agreements, as soon as Zuazo demonstrated how to manage and finance the project'. While the proposal has been studied over and over again, his idea of how to finance it has not. The remarkable thing about the project for a new axis little more than $5 \mathrm{~km}$ long from the Castellana $(1.857 \mathrm{~km}$ forming part of municipal Madrid and $3.148 \mathrm{~km}$ belonging to the immediate surroundings) is that he argued in favour of the need to construct social housing at the time that he favoured - hoping to make the proposal viable - locating homes for the upper and middle classes next to them. The city council would put them on the market in such a way that the project - completed by private business - would cost the council nothing.

In documents seized from Zuazo's studio during the Civil War and now deposited in the Civil War Archive, this idea is reflected through specifically pointing out how the fundamental idea of his plan was

...to link the Castellana extension with the construction of low-cost housing; thus combining the big land sale deal with the construction of economic housing and rented housing. There has been no mass production construction in Madrid. Most construction has been undertaken until now by insolvent people using the Mortgage Bank, mortgaging the initial cost of houses with interest from loans, producing less expensive buildings owing to the poor materials and low-quality labour employed.

The few districts of cheap housing already built have been constructed in a disorderly and disharmonious way, a profitable deal permitted by the Economic Housing Law; these districts have grown up on the periphery, on distant plots of land, in very deficient developments... ${ }^{20}$

Attempting to urbanize the north of the city and bring about - in the second section of the new avenue - the construction of large blocks of low-cost homes, Zuazo proposed to begin the development of the Castellana with the construction - in the third and fourth phases - of housing for the middle class (homes of $180 \mathrm{~m}^{2}$, with living room, dining room, five bedrooms and one service room). At the same time he proposed the construction of residential blocks for workers and the middle classes (the smallest type home would be $75 \mathrm{~m}^{2}$ ) as well as reserving the first phase (the closest to the existing city) for plots of land that could be sold on frankly profitable terms. And, also attempting to make the construction of the Castellana an attractive deal, he suggested building factories in the area surrounding the third zone for the industrial manufacture of bricks, cement blocks, and electrical systems.

The proposal detailed how $50 \%$ of the total land must be used for open patios, enclosed patios and gardens, stipulating that the last of these would be for inhabitants' private use. After affirming the need to construct 3000 homes (with different designs and dimensions) he specified that the average type must have four floors in addition to a ground floor, with 
colonnades linking the access to staircases. This would result in a total of 15,000 homes, so that that the new area would house some 90,000 new inhabitants. The data - unpublished until now - indicates that by calculating building costs at 100 pesetas $/ \mathrm{m}^{2}$ with a completed surface area of $231.250 \mathrm{~m}^{2}$, the total cost including development costs and construction (26,482,332 pts) and planned compulsory purchases $(12,936,643$ pts) would only reach 40 million pesetas, including the purchase of lateral fringes $50-\mathrm{m}$ wide, in line with regulations. ${ }^{21}$ As well as the desire to consolidate the urban fabric, Zuazo proposed to establish a large building in the new axis capable of uniting various ministries and embracing the city's train system. This would bring a new central station to the extreme end of the axis and establish (in his Regional Plan) a circular rail system that would have one of its stations beneath the Nuevos Ministerios (New Ministries) building. At the end of 1932 and the beginning of 1933 Zuazo received the two commissions, drawing up proposals that were immediately accepted and initiating the work. The large building would house the Ministries of the Interior, Public Works, Agriculture, Industry and Commerce, all of them united by a central section, in front of which there was a large honorary courtyard, separated from the large avenue by a series of arches that followed the direction of the Castellana extension. Once these works commenced, work on the large subterranean railway station began.

The 1933 elections condemned the project that, from 1934, was subject to drawn-out political disagreements. It was only restarted again in 1939 when one of Zuazo's collaborators (Pedro Bidagor, a man trusted by the Franco government) manipulated and corrupted the original concept and attempted - like Speer in Berlin - to establish a new city of Power as opposed to one of Social Peace, including (on Werner March's advice) a large stadium where Franco's regime could hold political gatherings. From 1934 the government marginalized Zuazo from all large official projects, and he had to concentrate instead on private architectural work, designing in conjunction with Eduardo Torroja the Frontón Recoletos. When Franco's 1936 military uprising took place, Zuazo, always loyal to the Republic, stayed in Madrid to work with the government. But when anarchist groups threatened him with death at the height of the war he decided to abandon the city and head for Paris. It was then that he received the previously mentioned invitation from Venezuela's consul general in Europe and an offer from the president of Colombia, giving him fresh hope and allowing him to design new plans.

While Zuazo could be positioned politically somewhere between the French definition of nonconformistes and planistes - and architecturally as a classicist along the lines of Bonatz - as an urban planner he defended both the idea of a large new axis - seen as a vital coordinating element of the new city - and a regional plan characterized by a series of satellite towns. He accepted the idea of Castellana around which would rise four-storey-high residential blocks in the vicinity of the Nuevos Ministerios, these high buildings contributing to the debate over Americanism in those years. And conscious of what the existence of such skyscrapers meant, he upset the traditional distance between blocks by making Castellana $120 \mathrm{~m}$ wide (Madrid's Gran Vía, built at the same time, had a width of $35 \mathrm{~m}$ ). In this sense his proposal (drawn up, let us not forget, in 1930) reflected more the French urban planning conceived by Prost at that time, rather than the plans set out slightly earlier in the CIAM at Brussels and Athens.

Both invitations came at a unique moment: the fact that Zuazo was invited to Colombia and Venezuela, and a few months later the President of Mexico General Cárdenas permitted the entry of thousands of exiles, reflected political transformation in those countries. During the 1930s and 1940s numerous Latin American republics experienced political change and a new spirit of national consciousness. Apart from Mexico (where a revolution had already 
consolidated 'the nation's invention'), other countries such as Colombia, Venezuela, Cuba, Argentina, etc. chose to reject their cultural legacy (not just colonial, but also the Beaux-Arts in Paris) in search of local roots. Populist governments abounded, and in their determination to connect with the popular masses they prioritized large infrastructure projects, for example, enlarging cities and constructing social housing. And in much the same way that in Weimar Germany a so-called 'conservative revolution' had resulted, many Latin American countries pondered the transformation of their old colonial cities not only into modern capitals, but above all into urban spaces representative of the New State. And of those countries mentioned, this phenomenon was particularly noticeable in oil-rich Venezuela.

Almandoz and Martín Frechilla have studied how at the end of the nineteenth century a policy based on the construction of public works developed in Caracas, resulting in the construction of aqueducts, a sewer system, bridges, roads, and public buildings. ${ }^{22}$ General Gómez's death in 1935 coincided with a strong surge in hydrocarbon exports, leading to the modernization of the country. New president López Contreras presented a modernizing plan (the socalled February Programme of 1936) in which he tackled changes to the administrative structure and aspects related to public health and social work, transport, national education, agriculture and livestock breeding, economic policy and commercial policy, as well as immigration. Attempting to define a political programme that would set it apart from that of his predecessor, President López Contreras hoped both to construct a capital that would be identified with 'nobility' and 'modernity', and have these labels applied to his government's policy and its idea of nation.

In some respects, such transformation attempted to mimic how many nineteenth-century European states (immersed in what would be defined as 'the invention of the Nation') had encouraged the study of archives, language, and historic architecture. Medieval documents served to demonstrate the special nature and identity of a nation, with past cultural roots. What was desired was not a simple urban renovation of historic areas but a radical alternative both to the colonial city and the nineteenth-century city, with construction of a directional axis that would establish the future urban development of a capital city. With such inspiration the Association of Venezuelan Engineers set out the Caracas Urban Planning Project in 1936.

In around 1930 some of the principal Latin American cities (Santiago de Chile, Bogotá, Rio de Janeiro, Buenos Aires, Montevideo, Sao Paulo, Caracas and Havana) witnessed spectacular growth and recognized the need to plan their transformation. Attempting to redefine the very concept of historical zones (what from another perspective was called 'the heart of the city') the political will to construct new capitals developed in tandem with enormous demographic changes. Buenos Aires increased from 950,000 inhabitants in 1904 to three million in 1947; Rio's 522,651 inhabitants in 1890 reached 2,377,451 in 1950; Caracas saw a similar increase between 1920 and 1940, passing from 92,912 to 324,317 inhabitants, and Bogotá's population increased from 40,000 at the end of the nineteenth century to 715,250 in around 1950. Politicians of those republics sought urban planners capable of taking on such plans, and approached European professionals, while ignoring their North American counterparts. In this way in the 1930 s and during the 1940 s the principal Latin American republics sought (be it the first Perón government; López Contreras and then Meina Angarita in Venezuela; Cárdenas in Mexico; the first Batista government in Cuba or Rojas Pinilla's last government in Colombia) to instigate large projects that would redraw the urban image of their cities, bringing about 
the arrival of professionals such as Rother, Brunner, Forestier, Rotival, Hegemann, Brünner, Agache, Rotival, Lambert, etc.

In recent years Latin American historiography has undergone a remarkable turnaround, replacing an out-of-date appraisal of its urban past (an erudite and sterile history based on extrapolated data) with analyses and ideas from historians who do not seek out national heroes. Instead they have attempted to identify contradictions, understand opposing opinions, and analyse how each of these has informed the development of contemporary cities. Francisco Liernur in Argentina (as well as Rosa Aboy and Anahi Ballent); Pérez Oyarzun, Rosas and Hidalgo, in Chile; Wiley Ludeña in Peru; Ruth Verde and Roberto Segre in Brazil; Enrique de Anda and Ernesto Alba in Mexico; Carlos Niño and Silvia Arango in Colombia, and Arturo Almandoz and Juan José Martín Frechilla in Venezuela, are some of the most important names practising this new historiography. Its uniqueness lies in having tackled - without, I understand, being conscious of it themselves - the same historical period (the first half of the twentieth century) from similar if not identical suppositions, putting aside studies of the colonial past. In this sense, the Caracas that was studied by Almandoz and Martin Frechilla has transformed (following the classic works by Carlos Raúl Villanueva and later published by Gasparini and Posani) into a pretext for understanding how European influences affected Latin America and analysing how architecture still linked to tradition (for example, the collection of 'The Silence' that the same Carlos Raúl Villanueva would design) was replaced by architecture free from any type of influence.

For years people wanted to assess and interpret modernity in Latin America with reference to its dependence on Le Corbusier's work. He was certainly invited to comment on how to intercede in various cities, but we must not forget that following his first visit to Latin America Le Corbusier himself recognized the problem/impossibility of transferring the high-rise building to the Latin American environment, even saying about Argentina's capital city '... Buenos Aires is the most inhuman city I have known: here, in truth, one's heart feels martyred'. To this comment he added in his Precisions sur l'urbanisme '. . . Latin America is an Eden where developed cultures are not apparent; the place where nature invokes wonder' and flatly condemning in his final commentary "... that in this same continent they continue to construct European buildings and, even worse, to construct with colonial pastiche influences'. Those who were invited to work in Latin America were neither architects nor urban planners linked to CIAM (cut off as a consequence from the 1932 debates held at CIRPAC in Barcelona, and the conclusions approved in Athens in 1933) nor the great urban planners of the USA.

During a period when the well-off Latin American middle-classes opted to send their children to study in the USA (not because there were no architectural schools at home, but because they were new and lacked the support and academic prestige of those in large US universities), it is odd that only occasionally did US architects and urban planners work in Cuba, Colombia, Venezuela and Mexico (without citing the more geographically distant countries in the continent). This is surprising when one reads Latin American architectural magazines, where it is easy to see how these middle-classes dreamed of enjoying the same comforts of US society as reflected in advertising for the latest materials, innovations for the house, and the first electro-domestic appliances. On the other hand another reality existed. Many Latin American architects began to understand that to identify what until then had been understood as 'Parisian fashion' was already mistaken considering that, as they had seen in the Decorative Arts Exhibition, influences for French architects had 
changed. At the same time severe criticism emerged of those who advocated following the 'radical' ideas of the European vanguard. Believing that Le Corbusier and the CIAM were attempting to spread and establish in Latin America the debates reflected in the Weissenhof of 1927, in the 1928 La Sarraz Congress and the CLAM held a year later in Frankfurt, they demanded such ideas as The soul of the people reflected in their art, and Guidelines for American architecture $^{23}$ in the same way that they argued against Le Corbusier's Maquinolatria (Machine-worship) arguing that (modern architecture should reject) '... economic laws, standardisation, Taylorism and engineering, that form the inspiration for art's "machine operators"... Because, as we said at the beginning, the theory of denying aesthetic value in lesser art is ... a natural result of 'Machine-worship' in art'. For this reason - for fear of 'offending' the middle-classes who supported their policies - it was deemed necessary to entrust large projects to architects capable of projecting a modern image remote from the formalism defended by Le Corbusier as well as the historical pastiche promoted by others. For this reason President Olaya Herrera invited the Austrian Karl Brunner to travel to Bogotá in 1933 and draw up an Urban Restructuring Plan, and in 1939 recently elected President Eduardo Santos Montejo proposed to Zuazo that he relocate to the same city. He would not only design the Presidential Palace and a ministerial building but also draw up a plan (and precise figures), forming part of a loan request that Colombia hoped to present to the US government.

In 1938 it was already possible to predict the end of the Civil War, with victory for Franco and a defeat for the Republic. Before political waverers and dissenters started to flee into exile, Zuazo decided to organize a team (confident of his possible departure for Bogotá) that included Santiago Esteban de la Mora from Madrid as well as the architects Germán Tejero de la Torre and Ricardo Ribas Seva. I doubt that Zuazo knew the last named man from Barcelona or had contact with the second younger and inexperienced architect, but he knew Santiago Esteban de la Mora well. He was a member of the OTM who - together with Lacasa y Colas - had first studied Zuazo's design for the Castellana project. He later reproached Zuazo with his intention to pass the management of the project into private hands, but he responded with a subtle and ironic comment that the difficulties encountered by his project were due to '... the young and inexperienced Municipal Technical Office'. His idea from the start was to bring together a team of trusted technicians - regardless of whoever else he could find later - and travel with them to Colombia. Brunner's work in Bogotá - as Director of the City Council Urban Planning Department - had been to design monumental avenues and institutionalize a policy of building working class neighbourhoods in the city. Zuazo's invitation was not intended to make him compete with the Austrian but rather, depending directly on the government, for him to set out and manage the large projects that the state intended to complete in the city, at a time when it was keen to transform Route 14 into Caracas Avenue. His invitation came about at a time when Bogotá's elite chose to move from the historic area of La Candelaria to a zone adjacent to the northern railway, moving from the centre to the north and making Chapinero their residential area. It was a period when the government was enjoying a propitious moment, when the benefits of agricultural exports were being invested in the purchase of large landed estates in the city's northern outskirts. It wanted to encourage construction, especially of infrastructure and non-residential buildings. Because of this, Zuazo received the invitation to travel to Bogotá. While Brunner had defined Caracas Avenue as an example of modernity, the Santos government needed to take the idea forward, turning therefore to large monumental proposals, 
requiring large US loans. The route to development therefore involved a policy of increasing the country's external debt.

As well as the Colombian proposal there was another from Venezuela, made under different circumstances. As Martin Frechilla has indicated, Venezuela's diplomatic mission in Paris at this time was a legation (rather than an embassy), and the invitation came from the Venezuelan minister. Both Almandoz and Martin Frechilla have studied in more depth than I the urban history of Caracas between 1935 - the year that General Gómez died - and the changes completed in the 1950 s by General Pérez Jiménez, both making reference to literature, economic studies and historical research from the period. The capital's Rotival Plan was based on proposals made in 1935 by the Société Française de Constructions de Batignolles to the Governor of Caracas Elbano Mibelli. The first contacts made with him came about due to the political changes carried out by López Contreras. He aimed to renovate the central heart of the city, modernizing and beautifying the city, while determining guidelines that would impact the city's expansion. Caracas hoped to transform itself from a rural capital into the great capital of a modern state. It was from this perspective that French technicians approached the Federal District government with proposals for various works of infrastructure that would solve some of the city's existing deficiencies. There followed a series of negotiations and proposals that lasted beyond the Second World War, when the then Colonel Maurice Rotival returned to Caracas at the request of the then minister Lander.

While the new capital would be a symbol of the new state, the new state would be synonymous with the government. The quest for national consciousness came about not only due to the emergence of a middle class linked to an economy based on oil wealth, but because of a need to assimilate a sudden wave of European immigration. These urban projects did not come about therefore as a result of speculative land deals but because a new government wanted to prove it was developing new areas of land. In 1920s' Europe the main priority had been to promote a policy of low-cost housing, giving rise to such disparate themes as standardization, a debate about minimum space, the characteristics of residential blocks and their relation to the city, outlying districts, regional plans, and transport as a communication solution, etc. In 1940s' Latin America, meanwhile, the ambition was to establish representative space, a symbolic capital in a new state. There was no attempt to define a new characteristic architectural language, as had occurred decades earlier in Mexico under Porfiriato's rule, and neither was there a desire - as outlined by the writer Lezama Lima - to define architecture in terms of light, ventilation, vegetation, and climate. And there was no ambition, as in certain European countries during this period, to erect examples of architecture that would stand as monuments. Instead they wanted imaginative proposals, capable of defining a new urban centrality and becoming symbols of the new capital.

Henri Prost ${ }^{24}$ was invited to preside over the plan, arriving in Caracas alongside Jacques Lambert and Maurice Rotival, the team responsible for organizing the expansion of the city. Martín Frechilla researched in his day what he called '. . . a story of diplomatic negotiations, contracts and obstacles'. It is known that Rotival imagined a Caracas that would develop around a great (Bolivar) avenue. It would embrace the gardens, boulevards, and open spaces of an urban landscape in line with Haussmann's vision, something desired during Guzmán's life. As Martín Frechilla has highlighted, from the moment that French technicians first proposed to the Federal District government to study Caracas until the Monumental Plan for Caracas was laid before the City Municipal Council in July 1939, the timeline of the French proposal was confusing to say 
the least. Once Mibelli had created the Federal District Town Planning Board in April 1938, it accepted in the same month the Caracas Urban Development Plan proposed by Prost, Lambert, Rotival y Wegenstein. The Board presented its initial plan in June 1938 and a second in August, with the Monumental Plan for the city formalized in July 1939. Its work, as Marta Vallmitjana has shown, ${ }^{25}$ ended with the presentation of the plan. However, a confrontation between the Ministry of the Interior and the Ministry of Public Works soon developed. This is because despite the plan's approval, a fundamental disagreement arose between the different administrations concerning decisions over several of its details. These included: the division of the city into zones (deciding where to locate working-class housing, public buildings); traffic and sanitation studies; cost for each phase and the total project; loans; municipal debt; expropriations, etc.

But why was Zuazo invited to participate in the design for the new Caracas, especially when there was already a commitment to Prost? The question should be framed I believe in the context of his valuable experience between 1920 and 1936 . He had proved his ability when planning and carrying out work in Seville, Bilbao, Zaragoza and Madrid, creating important plans for improvements and establishing guidelines for new urban centres, the starting points for outlying districts, and planning the short-term construction of new cities. As a developer, he had proved able in leading and organizing a talented team of architects and engineers, and identifying urban problems and deficiencies. As a businessman, he had worked with international banks, agreeing optimum terms to finance his projects. And finally as an architect, he had demonstrated his ability to assimilate various trends in modernism without abandoning urban designs drawn up on a large scale (Nuevos Ministerios), and therefore enhancing the urban environment. In Zuazo they did not seek so much his urban design but his ability to envision the future of the city without questioning what already existed. In Madrid, for example, his biggest concern had been to resolve the clash between the nineteenth-century city and its development, the meeting point between the old district and the new area for expansion.

The head of the Venezuelan legation in Paris had contacted Zuazo en 1938, at a time when it was impossible for him to have known about the conversations held between Prost's team and the government in Caracas. In his Memorias he recalls that he received scant information, consisting only of some maps and photographs of the city. It is vital to underline one fact: Rotival merely relied on his experience of urban planning, an aspect repeatedly ignored by Venezuelan historiography, which has always preferred - in line with the press commentaries published at the time - to present him as a 'great urban planner'. Zuazo, on the other hand, had behind him a wealth of experience not only as a designer but also as an urban developer. Because of that, when he received the proposed to leave for Caracas his first priority, in line with the guidelines from the ministry, was '.. . to construct a monumental avenue to be named Bolívar'. The only information given to him was the requirement to create an avenue running from west to east, $26 \mathrm{~m}$ wide and $3.75 \mathrm{~km}$ long, which would establish an axis for others that would run north to south. The 'information' that he would receive about the city was scarce to say the least, and because of this he drew - in what he called his Paris Notebooks - a plan of the Venezuelan capital, drawing his design ${ }^{26}$ in coloured pencils on the existing draft, perceiving just as Uslar Pietri would that

... we have the drawing of the original Caracas. A perfect square, divided into exact quadrangular blocks, with space for the main square and the market in the centre and, around them, the plots for 
the yet to be completed church and houses for the town council and the governor. It is the paper representation of how a future city should be, in accordance with the urban tradition of the Roman city and the wise foresight of the Laws of the Indies: close to water sources, on an incline that can drain rainwater, surrounded by forests and with easy access to the sea. ${ }^{27}$

On various occasions Rotival remarked on how the initial assignment consisted of "... making an avenue like Les Champs-Élysées that would terminate in the Caobos just as Les ChampsÉlysées terminated in the Bois de Boulogne'. This was the only guideline that would also reach Zuazo (we must not forget that his and the French team's designs were concurrent) and because of this, after analysing the position of green areas and water courses, he proposed a twofold plan that did not limit itself to planning a thoroughfare, linking the old quarter with Sucre Avenue and the Eastern Road. In the first instance, he proposed treating the area of Avenida Bolívar from the Parque Caobo to the cathedral (beyond the university building and the Capitol building) as a business district. An axis at the cathedral end divided the avenue into two branches, reaching the Calvario five blocks further on. At the same time he suggested two axes perpendicular to the other axis: one of these turning the actual Fuerzas Armadas Avenue into a business street for three blocks southwards, designing a new axis that would also link to the new city. Unlike the idea published shortly before by Luis Roche, Zuazo drew a series of fast-access routes in the vicinity of the existing Urdaneta Avenue (boosting as a consequence, the parallel University and Lecuna Avenues). He decided to make a new route from Bolívar to San Martin by drawing a new road between the existing Francisco Fajardo highway and Fuerzas Armadas Avenue. Duplicating his experience with the Castellana, Zuazo would design and would identify urban problems in Caracas. He gave Bolívar Avenue a new appearance, but at the same time understood that the basic problem in the new city involved traffic. Because of this, and in the face of the later division of Caracas into two cities (into east and west, with all it entailed for the division of social classes we see today) his overarching idea was to strengthen the urban centre, designing in this sense a radial system of large access roads that would link the historic centre to the area of expansion.

When the Civil War ended, Franco's government was able to make Venezuela withdraw its invitation through pressure from Ambassador Lequerica. When he returned to Spain in the same year 1939, Zuazo was prosecuted for 'political actions', barred from working professionally, and forced to live in the Canary Islands. We must not forget that he had never been active in any political party or held any political post. He returned to Madrid in 1943, and for the rest of his life Zuazo lived what he called 'a long internal exile', despite his recognition by everyone as the reference point for post-Civil War urban planning in Madrid.

\section{Notes}

1. Secundino Zuazo's typed Memorias, written in around 1967 , together with all the documents from his professional studio, were donated by his family to Madrid's National Library and can now be found in its Fine Arts section. Part of these Memorias (Zuazo Ugalde, Memorias 1919-1940) were published by the Comunidad Autónoma de Madrid in the same year. The paragraph cited appears on pages $351-352$ and $363-364$.

2. On the Rotival Plan for Caracas, see the collection El Plan Rotival. La Caracas que no fue, Caracas, 1991, as well as Frechilla, Diálogos reconstruidos para una historia de la Caracas moderna and Planes, planos y proyectos para Venezuela, 1908-1958 (Apuntes para una historia de la 
construcción del país). Also, by the same author, "El urbanismo francés en Venezuela de 1936 a 1950." Almandoz, Urbanismo europeo en Caracas (1870-1940) and Entre libros de historia urbana.

3. Maya, "Karl Brunner (1887-1960) el urbanismo como ciencia del detalle," $64-71$ as well as Hofer, Karl Brunner y el urbanismo europeo en América Latina. See also Castillo, Bogotá: el tránsito a la ciudad moderna 1920-1950 and Cortés, Del Urbanismo a la Planeación en Bogotá 1900-1990. Tarchópulos in her work (Las huellas del Plan para Bogotá de Le Corbusier, Sert y Wiener in Scripta Nova, revista electrónica de Geografia y Ciencias Sociales, 1) has indicated how with the exception of Lewis Mumford, English and US historiography has shown little interest in the experience of modern urban planning in Latin America, unlike recent books by some Italian and French authors (Almandoz, Emergence of Modern Town Planning. This call for attention coincides with that of Morshed ("Cultural Politics of Aereal Vision," 201-210): Western architecture has paid scant attention to South America because it has been seen as inert and exotic. It still awaits definition and co-option within the framework of Eurocentric historiography. On the role played by the government in the plans for Bogotá, see Niño, Arquitectura y Estado. Likewise, Hernandez, "Historian in the Construction."

4. On Spanish exile, see Giralt, Ciencia española en el exilio (1939-1989) El exilio de los científicos españoles. On exile in Venezuela and its relation with architecture, see Frechilla, "Sin solución de continuidad." and, by the same author, "Confianza, desazón y malestar." In the recent publication Arquitecturas desplazados: arquitecturas del exilio español Commissioner Henry Vincent unfortunately says nothing about the possible journey of Zuazo to Venezuela or Colombia.

5. Zuazo Ugalde, Memorias $1919-1940,351,355$ y $363-4$.

6. Ibid., 200.

7. On the interior colonization of 1920 s Spain, see Actas del Congreso "Los Poblados de colonización 1940-1971. On the specific topic of Zuazo, see Sambricio, "La 'revolución conservadora' y la política de la colonización en la España de Primo de Rivera," 61-72.

8. On Spanish participation in the London Congress, see Sambricio, "La normalización de la arquitectura vernacular," 21-44.

9. Giedion, "Gegen das Ich," 242-243.

10. Las Misiones Pedagógicas, Catalogo de la exposición celebrada en la Residencia de Estudiantes.

11. Fleischer, "Spanischer Städtebau aus vorrevolutionärer Zeit," 499-504. Also, Sambricio, "Hermann Jansen y el Concurso de Madrid de 1929," 8-15.

12. Plans by Jansen, Brix, Möring and Pedersen (published in Der Städtebau in November 1911) became known in Spain in 1910 thanks to articles published by de Montoliú firstly in the Boletín del Museo Social, 66-68 (explaining the exhibition held that year in Berlin) and also in the text by the same author Las modernas ciudades y sus problemas: A la luz de la Exposición de Construcción Cívica de Berlin (1910).

13. Maure, Secundino Zuazo and, by the same author, the Exhibition Catalogue of the exhibition held in Madrid's National Library with the title Zuazo, arquitecto de la Segunda República, Biblioteca Nacional, Madrid 2006.

14. Schubert, Die Gartenstadtidee zwischen reaktionärer ideologie und pragmatischer Umsetzung. Dortmunder Beiträge zur Raumplanung 117, Blaue Reihe, IRPUD, Dortmund 2004 as well as Reuther and Jansen, Neue Deutsche Biographie, 10.

15. Moderne Bauformen, back numbers corresponding to April 1930 and 1933.

16. Informe sobre la Ciudad, Madrid 1929.

17. Among the diverse plans found in the Plansammlung der Kunstwissenchaft Institut de la TU de Berlín can be found four plans (on vegetable paper) with cards in German in which the architect contributed to that competition. The originals by Zuazo form part of the previously cited Zuazo Bequest, deposited in Madrid's National Library.

18. Bonatz, Informe que el Sr. P. Bonatz, miembro del Jurado en representación de los concursantes extranjeros en Arquitectura, 404.

19. Zuazo Ugalde, Memorias 1919-1940, 221-229.

20. Ibid., 150-172. 
21. Zuazo. Proyecto de Edificación General de la Castellana. Archivo Histórico Nacional. Salamanca. Guerra Civil, sig. PS Madrid 1075. This consists of a file (labelled 'Nota Confidencial') given (without a date) by Zuazo for the Castellana residential development.

22. See note 21 above.

23. Martínez Inclán, "Diletantes y charlatans," 184.

24. On Prost's participation see the bibliography cited in note 4 highlighting Frechilla, El urbanismo francés en Venezuela de 1936 a 1950... and also see Hautecœur et al., "L'œuvre de Henri Prost," 321-323; Lyautey, "Henri Prost membre de l'Institut," 173; Marrast, Henri Prost, Bulletin SCA, L'Architecture, ler trimestre 1952, 13-16.

25. Vallmitjana, Caracas; Valery et al., Estudio De Caracas: Evolución del patrón urbano desde la fundación de la ciudad hasta el Periodo Petrolero, 1567/1936 as well as El Plan Rotival: La Caracas que no fue: 1939-1989. Un plan urbano para Caracas.

26. de Madrid. Fondo Zuazo Cuadernos de Paris. No reference number: these are some of the drawings that Zuazo drew in Paris during his exile and can be found in his previously cited bequest at Madrid's National Library.

27. AAVV El Plan Rotival. La Caracas que no fue. Instituto de Urbanismo. Facultad de Arquitectura y Urbanismo (FAU) Universidad Central de Venezuela. Caracas 1991. Ver en dicho libro el capítulo de A. Usar Petri, 8 .

\section{Notes on contributor}

Carlos Sambricio is a professor at the Departamento de Composición Arquitectónica, ETS Arquitectura de Madrid. He obtained his doctorate from Universidad Complutense (Pensamiento Arquitectónico en la España del XVIII) and l'EHESS of Paris (Madrid, Architecture et Urbanisme, 1925-1945). Author of Arquitectura española de la Ilustración (1986), Territorio y ciudad en España Ilustrada (1991), De Ciudad llustrada a la primera mitad del siglo XX (1999), and Madrid, vivienda y urbanismo. 190060 (2004). Editor of La vivienda experimental (1998); Un siglo de vivienda social (2003), and Habitation Minimun (1997). Becario de EHESS de Paris; DAAD alemana, Visiting Scolars del Getty Center y Harvard; Gast Profesor en Hochschule Bildende Künste Hamburgo and Profesore a contrato en Politecnico di Milano.

\section{Bibliography}

Actas del Congreso "Los Poblados de colonización 1940-1971. Conference Proceedings. Instituto Andaluz del Patrimonio Histórico. Sevilla, 2005. Forthcoming.

Almandoz, A. "The Emergence of Modern Town Planning in Latin America after a Historiographic Review." Paper presented at the Finnish research seminar on Latin America, Helsinki, 2003.

Almandoz, A. Urbanismo europeo en Caracas (1870-1940). Fundación para la Cultura Urbana [European Urbanism in Caracas (1870-1940). Foundation for Urban Culture]. Caracas: Editorial Equinoccio-Universidad Simón Bolívar, 2006.

Almandoz A. Entre libros de historia urbana. Para una historiografía de la ciudad y el urbanismo en América Latina [Between Urban History Books. Towards a Historiography of the City and Urbanism in Latin America]. Caracas: Editorial Equinoccio-Universidad Simón Bolívar, 2008.

Bonatz, P. "Informe que el Sr. P. Bonatz, miembro del Jurado en representación de los concursantes extranjeros en Arquitectura." Revista del Colegio de Arquitectos de Madrid t.XII (1930): 404.

Castillo, J. C. Bogotá: el tránsito a la ciudad moderna 1920-1950. Bogotá: Universidad Nacional de Colombia, 2003.

Cortés, R. Del Urbanismo a la Planeación en Bogotá 1900-1990. Bogotá: Universidad Nacional de Colombia, Facultad de Artes, Depto. de Arquitectura, 1995.

Fleischer, M. "Spanischer Städtebau aus vorrevolutionärer Zeit." Der Stadtebau XXVII (1932): 499-504.

Garrido, H. V. Catalogo de las Exposición Arquitecturas desplazados: arquitecturas del exilio español [Catalogue of the Exposition of Displaced Architecture: The Architectures of Spanish Exile]. Madrid: Ministerio de Fomento, 2007.

Giedion, S. "Gegen das Ich." Das Junge Deutschand, nos. 8-9 (1918): 242-243. 
Giralt, F. Ciencia española en el exilio (1939-1989) El exilio de los científicos españoles [Spanish Science in Exile (1939-1989). The Exile of Spanish Scientists]. Barcelona: Anthropos, 1994.

Hautecoeur, L., J. Marrast, J. Royer, and Th. Leveau. L' 'euvre de Henri Prost. Architecture et urbanisme [The Work of Henri Prost. Architecture and Urbanism]. Paris: Académie d'architecture, 1960.

Hernandez, F. "The Agency of the Historian in the Construction of National Identity in Colombian Architecture." In Globalization and Contemporary Art, edited by J. Harris, 389-423. Malden, MA: Blackwell, 2010.

Hofer, A. Karl Brunner y el urbanismo europeo en América Latina. Edita Corporación La Candelaria [Karl Brunner ad European Urbanism in Latin America. Ed. La Corporación La Candelaria]. Bogotá: Hoy Instituto Distrital de Patrimonio Cultural, 2003.

Lyautey, H. "Henri Prost membre de l'Institut." Urbanisme, no. 15, (1933): Republished in no. 57, (1958). 261.

Martin Frechilla, J. J. "El urbanismo francés en Venezuela de 1936 a 1950: Rotival y Lambert en una historia de gestiones diplomáticas, contratos y zancadillas." Estudios Demográficos y Urbanos 8, no. 2 (1993): $377-413$.

Martin Frechilla, J. J. Planes, planos y proyectos para Venezuela, 1908-1958 (Apuntes para una historia de la construcción del país) [Plans, Maps and Projects for Venezuela, 1908-1958. (Notes on the History of the Construction of a Country)]. Caracas (Apuntes para una historia de la construcción del país) [Reconstructed Dialogues on a History of Modern Caracas.], 446. Caracas: Universidad Central de Venezuela, 1994.

Martin Frechilla, J. J. "Confianza, desazón y malestar. Las relaciones de Venezuela con las dos Españas: 1936-1949." Paramillo, no. 16 (1997): 217-320.

Martin Frechilla, J. J. "Sin solución de continuidad: exilados e Inmigrantes españoles en la construcción de Caracas." Exils et migrations ibériques au XXeme siecle, no. 5 (1998): 207-248.

Martín Frechilla, J. J. Diálogos reconstruidos para una historia de la Caracas moderna. Caracas: CDCH-UCV, 2004.

Martínez Inclán P. "Diletantes y charlatans." Arquitectura y urbanismo, Colegio de Arquitectos de Cuba, nos. 94-95 (1941): 184.

Maure, L. Secundino Zuazo. Madrid: Colegio Oficial de Arquitectos de Madrid, 1987.

Maya, T. "Karl Brunner (1887-1960) el urbanismo como ciencia del detalle." Bitácora Bogotá (2004): 64-71.

Montoliu, C., ed. Las modernas ciudades y sus problemas: A la luz de la Exposición de Construcción Cívica de Berlín 1910 [Modern Cities and Their Problems: On the Civic Construction of Berlin, 1910]. Barcelona: Sociedad Cívica Ciudad Jardín, 1913.

Montoliú, C. La Exposición Universal de Construcción Cívica de Berlín Boletín del Museo Social, no. 2 (1910): 66-68.

Morshed, Adnan. "The Cultural Politics of Aereal Vision: Le Corbusier in Brazil (1929)." Journal of Architectural Education 55, no. 4 (2002): 201-210.

Niño, C. Arquitectura y Estado [Arquitectura y Estado]. Bogotá: Editorial de la Universidad Nacional de Colombia, 2003.

Reuther, H., and Hermann Jansen. Neue Deutsche Biographie [New German Biography]. Berlin: Duncker and Humblot, 1974.

Sambricio, C. "Hermann Jansen y el Concurso de Madrid de 1929." Arquitectura no. 303 (1995): 8-15.

Sambricio, C. "La normalización de la arquitectura vernácula. Un debate en la España de los veinte." Revista de Occidente, no. 235 (2000): 21-44.

Sambricio, C. "La 'revolución conservadora' y la política de la colonización en la España de Primo de Rivera." In Pueblos de colonización durante el franquismo: la arquitectura en la modernización del territorio rural [Agrarian New Towns During Franquism: Architecture in the Modernization of the Rural Territory], 61-72. Sevilla: Instituto Andaluz del Patrimonio Histórico, 2008.

Schubert, D. Die Gartenstadtidee zwischen reaktionärer ideologie und pragmatischer Umsetzung. Theodor Fritschs völkische Version der Gartenstadt [The Garden City Idea Between Reactionary Ideology and Pragmatic Implemention: Theodor Fritsch's National Version or Garden City]. Dortmunder Beiträge zur Raumplanung 117, Blaue Reihe, IRPUD, Dortmund 2004. 
Tarchópulos, Doris. "Las huellas del Plan para Bogotá de Le Corbusier, Sert y Wiener in Scripta Nova." Revista electrónica de Geografía y Ciencias Sociales X, no. 218 (86) (2006).

Valery, R., M. Vallmitjana, and A. Morales. Estudio De Caracas: Evolución del patrón urbano desde la fundación de la ciudad hasta el Periodo Petrolero, [Study of Caracas: The Evolution of the Urban Plan from the Founding of the City Until the Age of Petroleum] 1567/1936. Caracas: Universidad Central de Venezuela, 1988.

Vallmitjana, M., ed. Caracas: nuevos escenarios para el poder local. Caracas: PNUD, 1993.

Zuazo Ugalde, S. Memorias 1919-1940. Madrid y sus anhelos urbanísticos [Memoirs 1919-1940. Madrid and Its Urban Yearnings]. Madrid: Comunidad de Madrid, 2003. 